\title{
Effect of Combined Stresses on Fiber- Epoxy Composite Curved Pipe
}

\author{
Fadhel Abbas Abdullah \\ Omar Emad Shukry \\ Mechanical Engineering Department, Al-Mustansiriayah University, Baghdad, Iraq. \\ fadhe1975@yahoo.com
}

\begin{abstract}
The aim of this research is to study the behavior of fiber epoxy composite curve pipe under internal pressure and bending moment. The specimens made from woven roving (Mat) fiber glass pipes and epoxy composite with 50\% volume fraction are used to manufacturing curved pipe. The experimental work included manufacturing pipe specimens by vacuum bag technique. Pipe specimens were having $100 \mathrm{~mm}$ inner diameter, $450 \mathrm{~mm}$ length of curvature center line of curve pipe with (43 degree) and two wall thickness are 4 and $3 \mathrm{~mm}$. The test rig was designed and performed to study the effect of internal pressure and bending moment on the composite pipes. Also, the tensile test of the samples was done. The analytical expression solution has been accomplished to determine the strain, stress, for hoop and longitudinal direction. It is evident that the hoop stress for woven roving fiber composite pipe was more than longitudinal stress by almost (14\%). The maximum internal pressure in the case of internal pressure only was more than compared to the combined internal pressure with bending moment by almost (115\%). The most dangerous region is found in the inner arc of the curved pipe (intrude) area.
\end{abstract}

Keywords: Composite curve Pipes, Internal pressure, Stresses.

\section{Abbreviations}

$\begin{array}{llc}\mathrm{D}, \mathrm{d} & \text { Out and Inner diameter } & \mathrm{mm} \\ \mathrm{E} & \text { Modulus of elasticity } & \mathrm{GPa} \\ \mathrm{E} 1 & \text { modulus of elasticity in 1 direction } & \mathrm{GPa} \\ \mathrm{E} 2 & \text { modulus of elasticity in 2 direction } & \mathrm{GPa} \\ \mathrm{Li}, \mathrm{Lc}, \mathrm{Lo} & \text { Length of inner ,center and outer arc } & \mathrm{mm} \\ \mathrm{P} & \text { Internal pressure } & \mathrm{MPa} \\ \mathrm{R} & \text { Mean radius of curve pipe } & \mathrm{mm} \\ \theta & \text { Angle of curve pipe } & \text { degree } \\ \Phi & \text { Location of strain gauge around circumference of a pipe degree } \\ \sigma_{\mathrm{H}}, \sigma_{\mathrm{L}}, & \text { Hoop and Longitudinal stress } & \mathrm{MPa} \\ \varepsilon_{\mathrm{H}}, \varepsilon_{\mathrm{L}} & \text { Hoop and Longitudinal strain } & \\ (v) & \text { Poisson ratio } & \end{array}$


Journal of University of Babylon for Engineering Sciences, Vol. (26), No. (7): 2018.

\section{Introduction}

Curved pipes are very important and common components of piping systems that can be found almost in many applications. Pipe bends are used extensively in piping systems, not only to change the direction of a pipe line, but also to provide flexibility. Pipe bends are widely used in industry, in particular, applications include large-diameter in chemical complexes, desalination plants, water supply and nuclear power stations [1]. Today, the modern use - composite materials in the oil industry becomes more and more apparent. This is due to benefit from them, and reduce the weight of construction up to $80 \%$ indeed, the use of piping systems for fluid transfer and pressure vessels, drill pipe, and tanks for storing liquids, platforms to protect against fire etc., fiber glass tubes usually for a period of 50 years while the metal tubes for a period of 10-15 years because of corrosion [2].Cross sectional deformation is known to give a pipe bend 5-20 times the flexibility of a straight pipe of the same material and size. This flexibility is not gratuitous however; it is typically accompanied by stresses and strains that are 3-12 times[3].[4] Studied the ultimate failure load of composite of filament -wound fiber - reinforced composite for pipe elbow subjected to combined load. Results showed that in the first case, the elbow subjected to internal pressure loading only will try to straighten due to the difference surface area between the intrados and the extrados. The most dangerous area in which the stresses were concentrated in the intrude and in the area of the crown and the least region was in the extrude of the pipe bend or elbow. [5] studied the stress analysis of Steel Elbow pipe in four pipes and compared them to the straight pipe. It is subjected to an internal pressure (12.5 MPa). The results showed that the location for high stress was in the inside part of the curve pipe or extrude region for small pipe and along the sides for larger pipes, It is believed that the reason the large pipes have this high stress on the sides is that the larger pipes have a local section change due to the high stress .The max. Stress in elbow pipe is more than in straight pipe with same material. [6] Studied the finite element models of buried Glass Reinforced Composite (GRC) pipes used in the transfer of fuel through a diameter of $400 \mathrm{~mm}$, and consists of multiple components, such as a hole valve, (45 degree and 90 degrees) tube bends. In this paper, two cases are presented to study the buried pipe response, Models A (45degree bend) and B (90-degree bend) consist of 511242 and 584056 linear elements respectively in terms of the induced hoop stress and the resulting pipe displacement, after application of pipe pressure $1 \mathrm{MPa}$ and geostatic loads. The hoop stress (97 $\mathrm{MPa}$ ) and axial stress $(59 \mathrm{MPa})$. For the pipeline, it is recommended from, literature that excessive should be avoided so as to prevent pipe wall buckling or wrinkling. The maximum hoop stresses are generally occurring at the connections and are within in intrude location and in the crown for axial stress. The deformation in hoop direction is more than in axial direction. The findings revealed that the effect of the internal pressure and the loads reduce pipe ovalization. But tend to increase axial stresses in the pipe bends. [7] studied the strain or deformation of elbow steel pipe bend subjected both closing mode and opening mode bending tests were completed and internal pressure. The steel pipe bends were highly deformed and wrinkled before the crack began, in the case of the bending closure mode. The aim of this research is study experimentally the behavior of curved composite pipe with different material under internal pressure. 
Journal of University of Babylon for Engineering Sciences, Vol. (26), No. (7): 2018.

\section{Experimental work}

\subsection{The Material Properties}

In present work the composite material content from woven roving fiber glass (Mat) and epoxy resin as shown in figures (1 and 2). Table (1) shows the properties of epoxy resin and fiberglass.

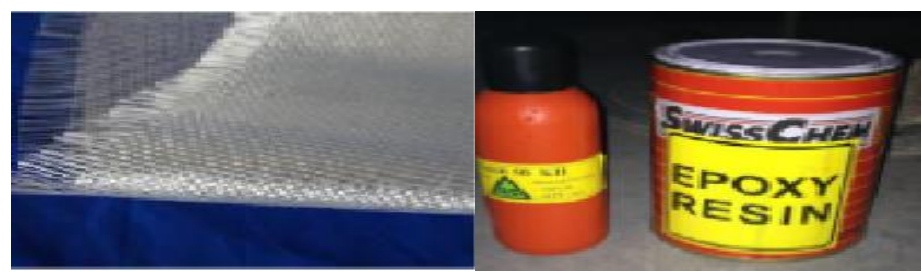

Figure 1. The Fiber Glass

Figure 2. The epoxy resin

Table1. The Properties of Epoxy, fiberglass

\begin{tabular}{lcc}
\hline \multicolumn{1}{c}{ Material } & $\begin{array}{c}\text { Young's modulus(E) } \\
(\mathrm{GPa})\end{array}$ & Poisson Ratio $(\boldsymbol{v})$ \\
\hline Fiber Glass (Mat) & 72.4 & .25 \\
Epoxy & 3.8 & .33 \\
\hline
\end{tabular}

\subsection{Preparation of Samples}

The volume fraction in this work is $50 \%$, the thickness of specimens are $(4 \mathrm{~mm})$ and (3 $\mathrm{mm})$, as shown in table (2).

Table (2) Thickness and Number of Layers of the present work

\begin{tabular}{cccc}
\hline Material & Thickness of layer $(\mathrm{mm})$ & No. of Layer & Thickness $(\mathrm{mm})$ \\
\hline G.M.4 & 0.25 & 8 & 4 \\
G.M.3 & 0.25 & 6 & 3 \\
\hline
\end{tabular}

\section{Where:}

G.M.4 Fiber Glass Mat at 4mm thickness

G.M.3 Fiber Glass Mat at 3mm thickness

The specimen used with specific dimensions is shown in figure (3).

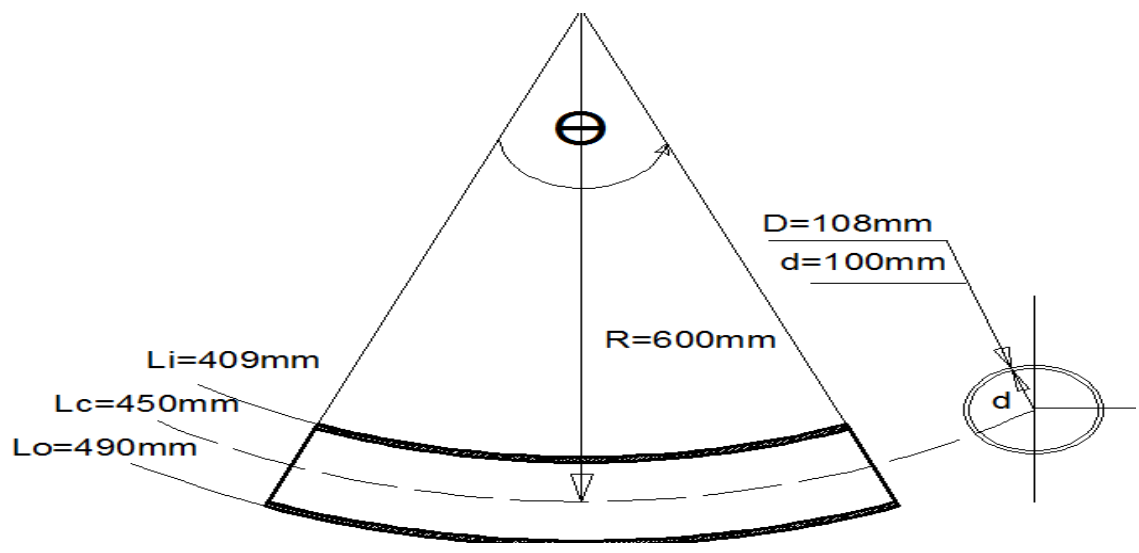

Figure 3. Dimension of specimen 


\subsubsection{Molding and Cutting}

The following steps will be implemented:-

1. A gypsum mold with the same dimensions of specimen curve pipe was placed on iron pipe then Grinding it by smooth sand paper saturated by water,

2. The gypsum mold will be taken and connected to the vacuum device

3. preparing the (PVA) sack (bag) which was made from polyvinyl alcohol

4. The gypsum mold will be saturated with little water while wiping it by type of lotion cream from outside of the (PVA) sack to avoiding tear it during inserting the gypsum mold inside it

5. Then the mold was inserted in a sack, this sack was closed tightly from bottom and top as shown in figure (4)
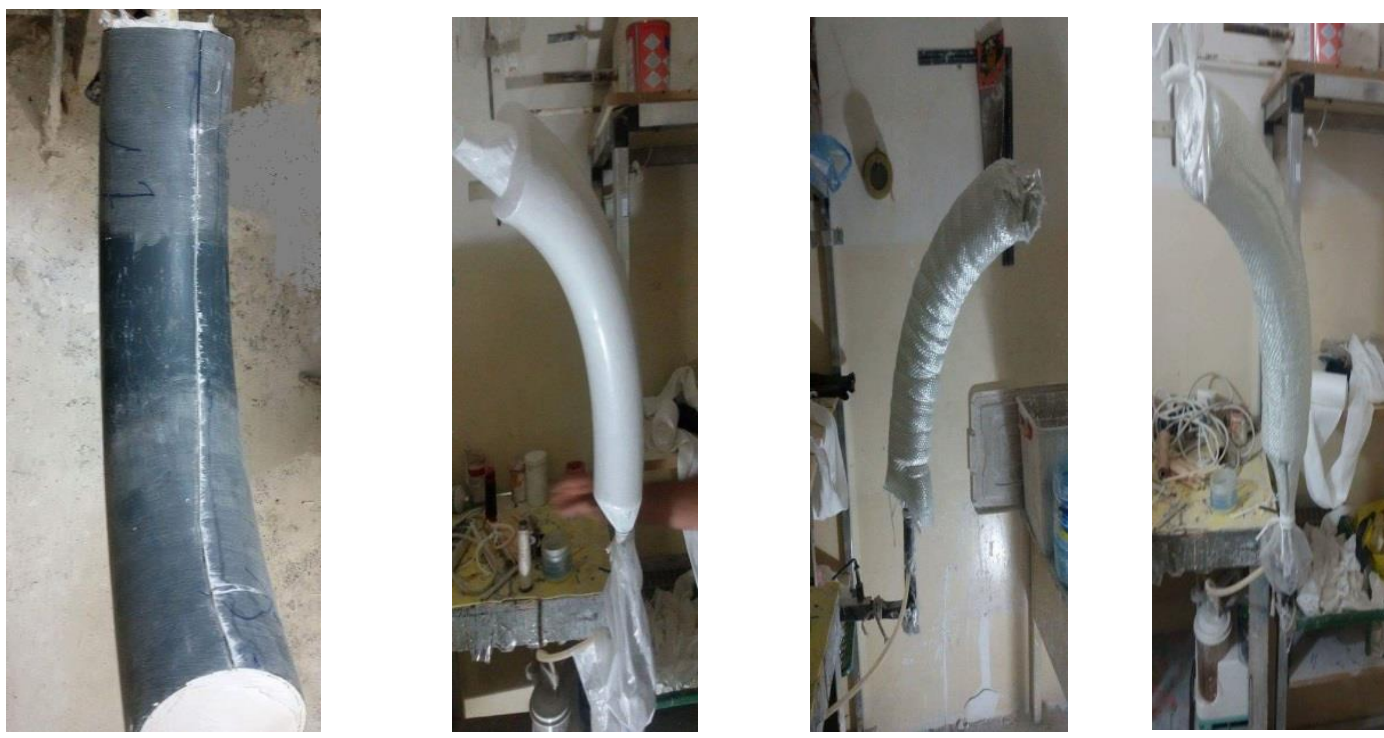

\begin{tabular}{|c|c|c|c|}
\hline $\begin{array}{c}\text { gypsum mold same } \\
\text { dimension of } \\
\text { specimen was } \\
\text { placed on iron } \\
\text { Pipe }\end{array}$ & $\begin{array}{c}\text { insert first PVA } \\
\text { bag }\end{array}$ & $\begin{array}{c}\text { Roving glass fiber on } \\
\text { the PVA by layers } \\
\text { around the mold and } \\
\text { even get the desired } \\
\text { thickness }\end{array}$ & $\begin{array}{c}\text { INSERT } \\
\text { second } \\
\text { PVA }\end{array}$ \\
& & \begin{tabular}{c} 
\\
\hline
\end{tabular}
\end{tabular}

Figure (4) Molding Process Curve Pipe

6. Roving glass fiber on the (PVA) by layers around the mold and get the desired thickness then placed another second (PVA) and closed it from the top and bottom to avoid exit the epoxy resin.

7. Opening vacuum device to avoid the presence of any bubbles inside the matrix and epoxy resin poured inside from top of (PVC), then redistribute inside the (PVA) by hands as shown in figure (5).

8. The same technique is followed for molding and casting the woven roving fiber glass and woven roving carbon fiber. 


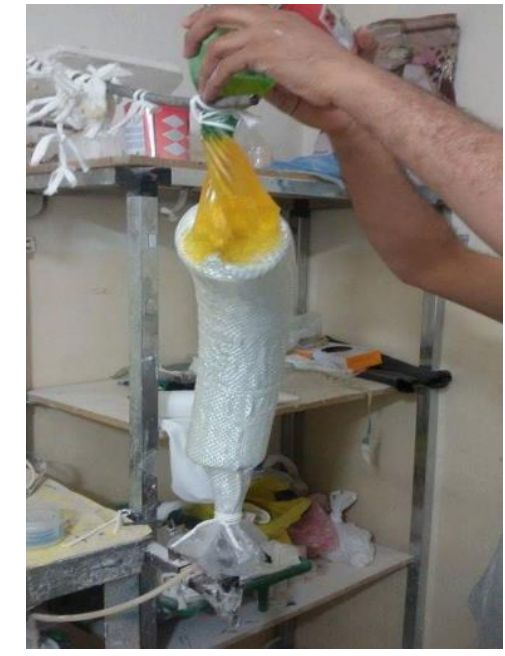

Opening vacuum device \& Epoxy resin poured inside from top of PVC to avoid bubbles

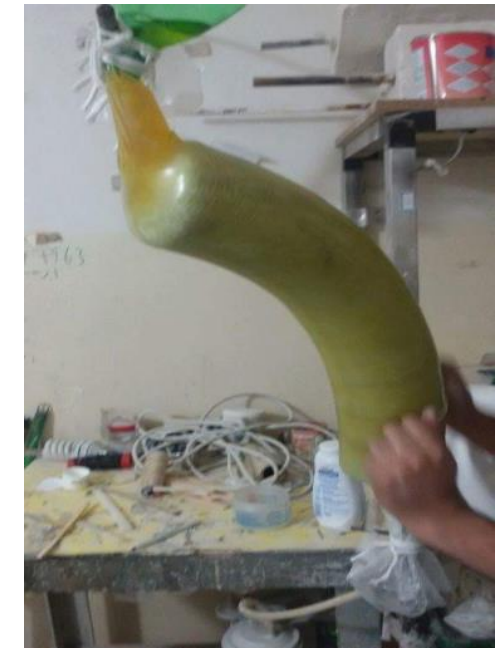

Then redistribute inside the PVA by hands

Figure (5) Casting Process

After finishing cast the specimen has been cut as it shown in figure (6) .

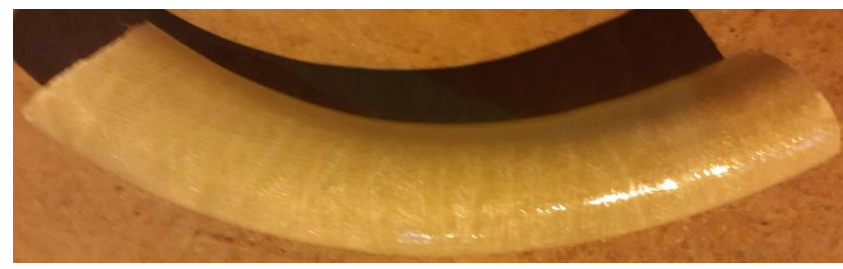

Figure 6. The Image of Specimens

\subsubsection{End Fittings Design}

For research tests, involving the pressure of the sample tubes, it was necessary to design an appropriate end-fitting for the task, thus, the presence of a strong joint between pipes ends and fittings is necessary, therefore, the two end fittings are designed to prepare the test as shown in figures (7), (8).

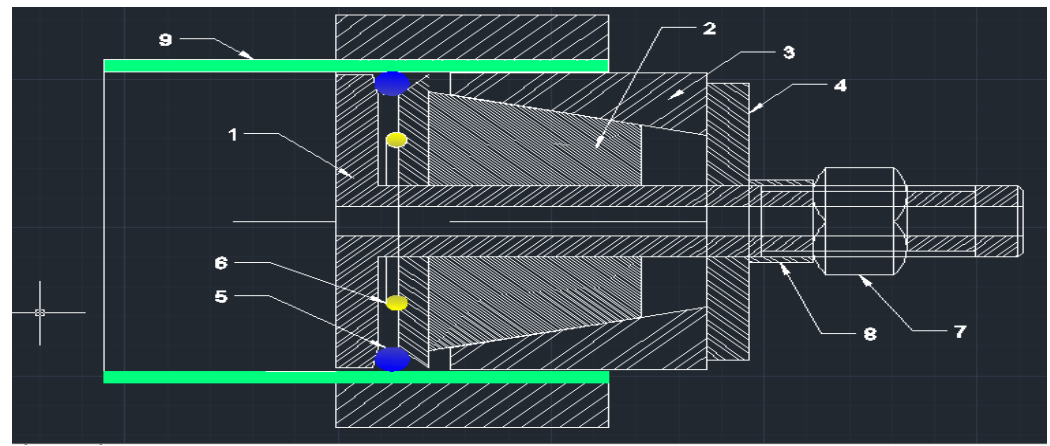

1, 2,3 = Compressing parts $5,6=$ Rubber seal, $4=$ Flange, $7=$ Nut, $8=$ bush, $9=$ Composite pipe Figure (7). Design of Mechanical End Fitting 


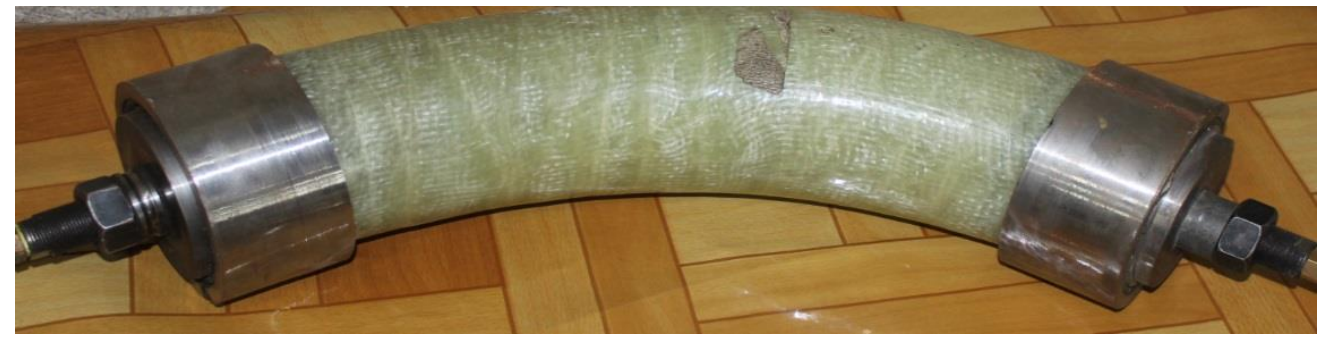

Figure 8. The Image of Specimens with End Fittings

\subsection{Pressure system}

The system records the change in internal pressure with the change in length and time during the test. The compression system has been designed so that multiple loading conditions can be facilitated, while at the same time carrying internal pressure is lower than the yield point for each sample. Figure (9) illustrates the Specimens with manual oil compressor. The oil compressor can produce up to (300 bar).

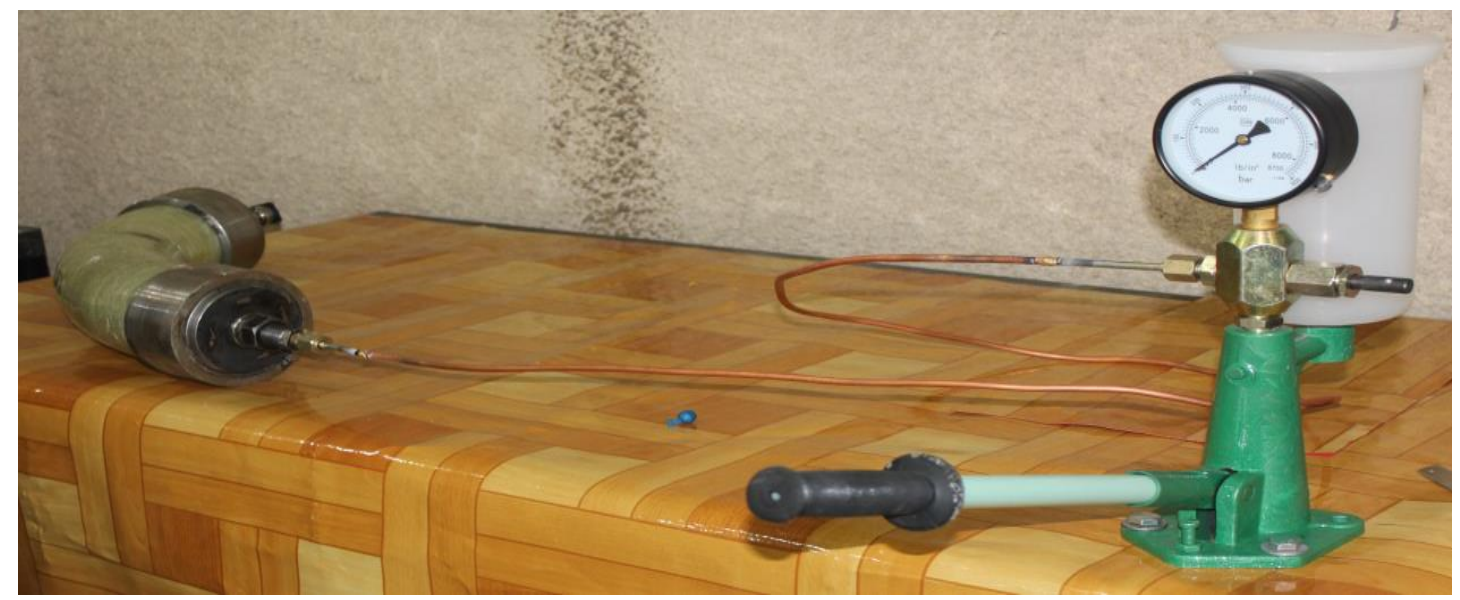

Figure (9). The Image of Specimens with manual oil compressor

\subsubsection{Pressure Transducer}

A pressure adapter is a sensitive device that continuously transmits the pressure inside cylinder, the controller uses this information to regulate pressure and avoid overpressure conditions. The compression adapter is connected to the digital universal data logger, data recorder from a signal converter from the pipe to data recorder program in the computer to display reading the pressure as shown in figure (10).

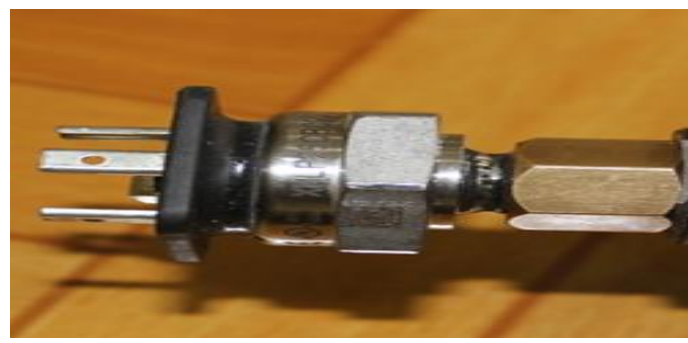

Figure (10) Pressure Transducer 


\subsubsection{Digital Universal Data Logger}

This device transforms the change in resistance that occurs in the strain gage or pressure transducer to a value in mill amperes as an output value. Eliminates the use of Whitstone Bridge, this device has five ports shown in the figure (11), using one port for pressure transducer. It is also connected to the computer to display reading of pressure in each test.

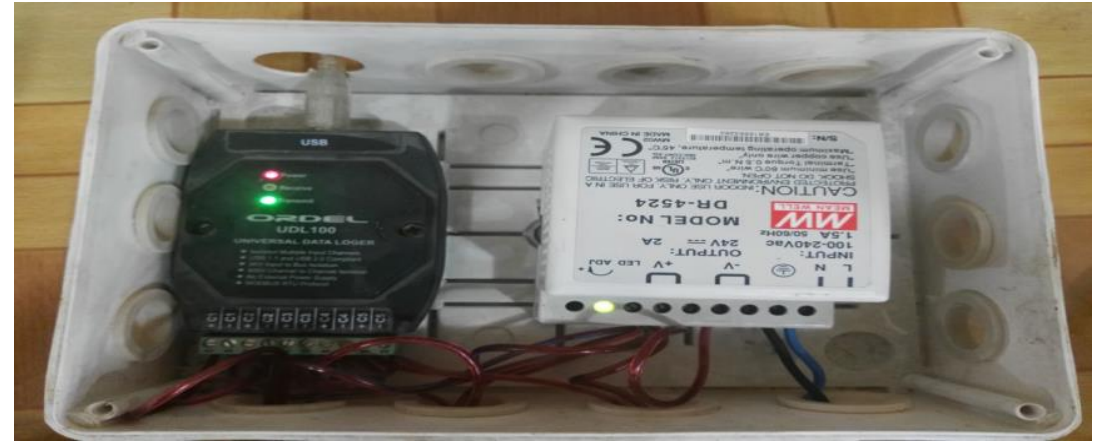

Figure (11) a view of Universal Data Logger

\subsubsection{Data acquisition system data}

\subsubsection{Strain Gage set -up}

Strain gage is a device in which the electrical resistance varies proportionally with strain change, is the most common method of measuring strain due to traditional size and simple installation, strain gages properties $(\mathrm{R}=120 \Omega, \mathrm{GF}=2.07$ and grid length $=(30 * 10 \mathrm{~mm})$ for recording the strain data, two strain gages are bonded on the surface in the middle of curved pipe (crown )at angle $\varphi=0^{\circ}$ and it placed in vertical and horizontal directions to read the hoop and longitudinal strain and bonding two strain gages in bottom or outer arc (extrude) at angle $\varphi=90^{\circ}$ and bonding two strain gages in the inner arc of the curved pipe (intrude) at angle $\varphi=-90^{\circ}$ and shown in figure (12) and figure (13) to show the six strain gages with angle.

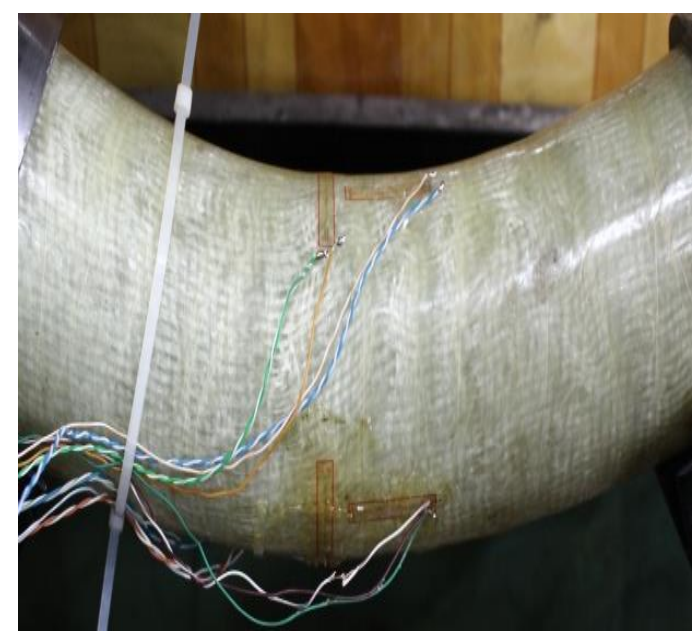

Figure (12) A view of Strain Gage on the Pipe

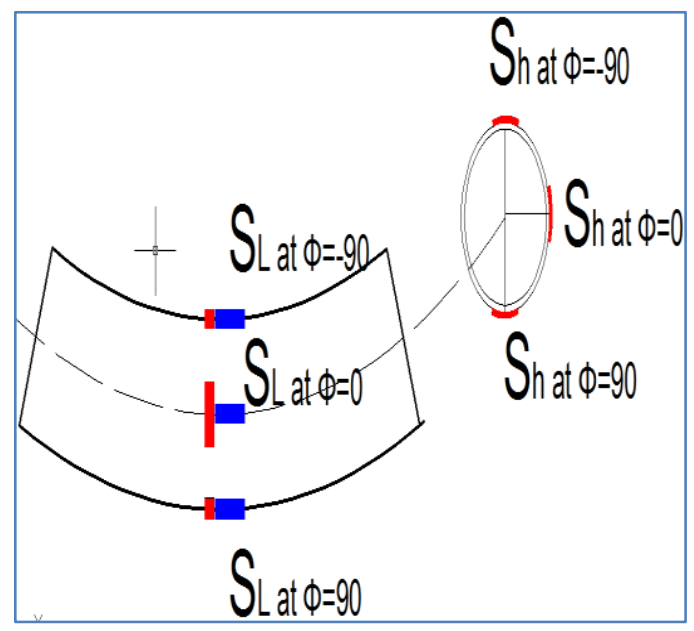

Figure (13) A view of Strain Gage with angle $\varphi$ 


\subsubsection{NI 9235}

NI 9235 quarter-bridge strain gage modules with eight simultaneous channels per module [8] using six of them only, as shown in the figure (14). Where the NI 9235 was used to measure the strain of the strain gages, which converts data in volt with time.

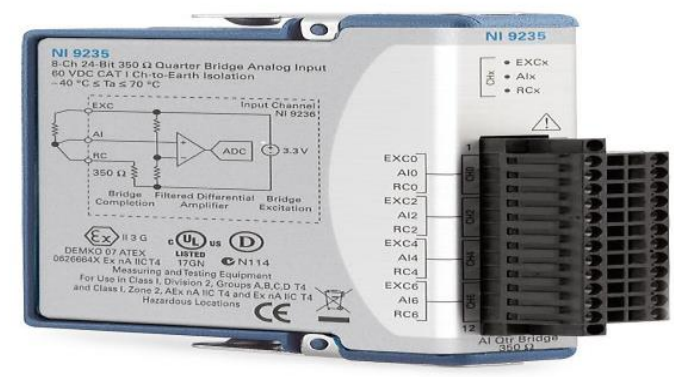

\section{Figure (14) NI 9235 USB Data Acquisition Systems}

\subsection{Tensile tests}

Mechanical properties of all samples were measured in accordance with ASTM D 638 [9]. There were three samples per specimen with $(57 \mathrm{~mm})$ length and $(13 \mathrm{~mm})$ width and thickness is $(3 \mathrm{~mm})$ and $(4 \mathrm{~mm})$, Figure (15) shows the shape of tensile samples of glass fiber with thickness $(4 \mathrm{~mm})$. Elastic modulus and poisson ratio used in the present study which got it from experimental tensile test and used in stresses equation (1), (2), as listed in table (3).

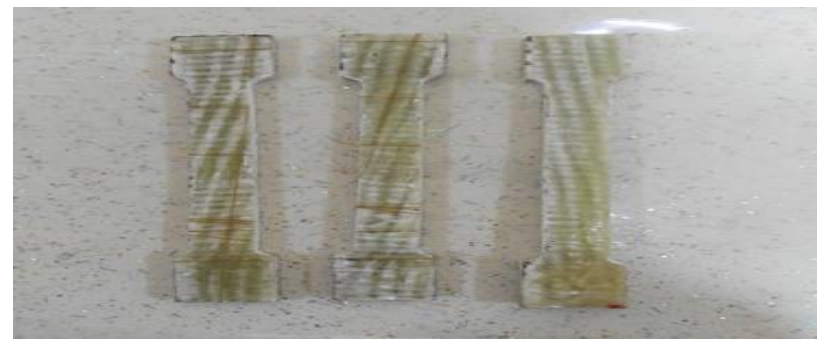

\section{G.M.4}

Figure (15) Shape of Tensile Samples

Table (3) Experimental Tensile Test Values, Young Modules and Poisson ratio

\begin{tabular}{ccccc}
\hline $\begin{array}{c}\text { Symbol } \\
\text { material }\end{array}$ & $\begin{array}{c}\mathrm{E} 1 \\
(\mathrm{GPa})\end{array}$ & $\begin{array}{c}\mathrm{E} 2 \\
(\mathrm{GPa})\end{array}$ & $\boldsymbol{v}_{\mathbf{1 2}}$ & $\boldsymbol{v}_{\mathbf{2 1}}$ \\
\hline G.M.4 & 23.4 & 23.4 & 0.319 & 0.319 \\
G.M.3 & 25.6 & 25.6 & 0.32 & 0.32 \\
\hline
\end{tabular}

\subsection{Calculation of Longitudinal and Hoop Stresses of the Specimen}

Stresses equation should be found in term of strain [10], because of the results are obtained from the experimental work. Where the stresses can be calculated according to the mechanical properties of each specimen material. 
$\sigma_{L}=\frac{E_{2}}{\left(1-v_{12} v_{21}\right)}\left[\epsilon_{H} v_{12}+\epsilon_{L}\right]$

$\sigma_{H}=\frac{E_{1}}{\left(1-v_{12} v_{21}\right)}\left[\epsilon_{H}+v_{21} \epsilon_{L}\right]$

\section{Results and Discussion}

In this work, the pressure versus the stresses and strain behavior are presented the variation of strain and stresses with the pressure increment are shown in figure (16) to (22). It can be seen that, the composite curved pipes which was woven roving (MAT) fiber glass at thickness (4 and $3 \mathrm{~mm}$ ) in hoop and longitudinal direction (G.M.4.H), (G.M.4.L) and (G.M.3.H), (G.M.3.L). Figure (16) gives the relationship between internal pressure reaching up to $(8.2 \mathrm{MPa})$ and the hoop strain $\boldsymbol{\varepsilon}_{\boldsymbol{H}}\left(\varepsilon_{\mathrm{H}}\right)$ for (G.M.4.C), at three angles $\left[\Phi=90^{\mathrm{O}}, \Phi=-90^{\mathrm{O}}, \Phi=0\right]$. The increase in $\left(\varepsilon_{\mathrm{H}}\right)$ in angle $\left(\Phi=-90^{\circ}\right)$ with increasing pressure was very clear and more than $\left(\varepsilon_{H}\right)$ in the crown position by $(75 \%)$, the hoop strain $\left(\varepsilon_{H}\right)$ in the crown position is more than $\left(\varepsilon_{H}\right)$ in extrados position by $(33 \%)$. due to curved pipes when subjected to internal pressure will try to straighten due to the difference surface area between the intrude and extrados.

Figure (17) shows the relationship between growing in internal pressure reaching up to (8.2) $\mathrm{MPa}$ with longitudinal strain $\varepsilon \mathrm{L}$ at three angles $\left[\Phi=90^{\mathrm{O}}, \Phi=\right.$ $\left.90^{\mathrm{O}, \Phi}=0\right]$. The increase in $\left(\varepsilon_{\mathrm{L}}\right)$ in angle $\left(\Phi=0^{\mathrm{O}}\right)$ with increasing pressure was very clear and more than $\left(\varepsilon_{L}\right)$ in the intrude position by $(70 \%)$, the longitudinal strain $\left(\varepsilon_{L}\right)$ in angle $\left(\Phi=-90^{\circ}\right)$ (intrude position) is more than the $\left(\varepsilon_{L}\right)$ in extrados position by $(120 \%)$. For the same specimens (G.M.4.H), (G.M.4.L), figure (18) and figure (19) show the influence of the pressure increment on the stresses [hoop stress $\left(\sigma_{H}\right)$, longitudinal stress $\left.\left(\sigma_{\mathrm{L}}\right)\right]$. It is noted that all stresses increased with the growing in pressure. Also, note that the hoop stress $\left(\sigma_{H}\right)$ in angle $\left(\Phi=-90^{\circ}\right)$ in figure (17) is more than $\left(\sigma_{\mathrm{H}}\right)$ in (crown position ) by $(35 \%)$, the hoop stress $\left(\sigma_{\mathrm{H}}\right)$ in (crown position) is more than $\left(\sigma_{\mathrm{H}}\right)$ in extrados position by $(61 \%)$, as well as the longitudinal stress $\left(\sigma_{\mathrm{L}}\right)$ in angle $\left(\Phi=0^{\mathrm{O}}\right)$ in figure (18) is more than $\left(\sigma_{\mathrm{L}}\right)$ in the intrude position by $(19 \%)$, the longitudinal stress $\left(\sigma_{\mathrm{L}}\right)$ in intrude position is more than $\left(\sigma_{\mathrm{L}}\right)$ in extrados position by $(111 \%)$. Figure (20), (21), (22) and (23) give the same relationship as figure (16), (17), and (18) and (19) respectively, but now with thickness of (3mm) for woven roving glass composite pipe (G.M.3). It can be seen from these figures, the following results: The pressure increment reaching up to (4.5) $\mathrm{MPa}$, as listed in table (4)

Table (4) Results of the glass fiber specimens under internal pressure only

\begin{tabular}{|l|c|c|c|c|c|c|c|c|c|c|c|c|}
\hline \multirow{2}{*}{ type } & \multicolumn{4}{|c|}{$\Phi=90^{\circ}$} & \multicolumn{4}{c|}{$\Phi=0^{\circ}$} & \multicolumn{4}{c|}{$\Phi=-90^{\circ}$} \\
\cline { 2 - 14 } & $\sigma_{\mathrm{L}}$ & $\sigma_{\mathrm{H}}$ & $\varepsilon_{\mathrm{L}}$ & $\varepsilon_{\mathrm{H}}$ & $\sigma_{\mathrm{L}}$ & $\sigma_{\mathrm{H}}$ & $\varepsilon_{\mathrm{L}}$ & $\varepsilon_{\mathrm{H}}$ & $\sigma_{\mathrm{L}}$ & $\sigma_{\mathrm{H}}$ & $\varepsilon_{\mathrm{L}}$ & $\varepsilon_{\mathrm{H}}$ \\
\hline G.M.4 & 22.8 & 29.8 & .0005 & .0009 & 57.5 & 48 & .0018 & .0012 & 48.2 & 64.9 & .0011 & .0021 \\
\hline G.M.3 & 26 & 34 & .00059 & .001 & 65.6 & 54.8 & .00187 & .00132 & 55 & 74.1 & .00117 & .0022 \\
\hline
\end{tabular}




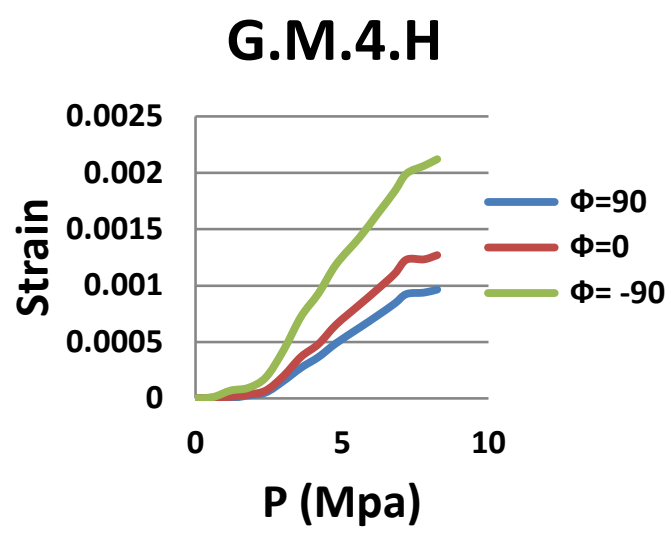

Figure (16) Hoop strain $\left(\varepsilon_{H}\right)$, for glass woven roving, with angle $\Phi=90, \Phi=0$, $\Phi=-90$

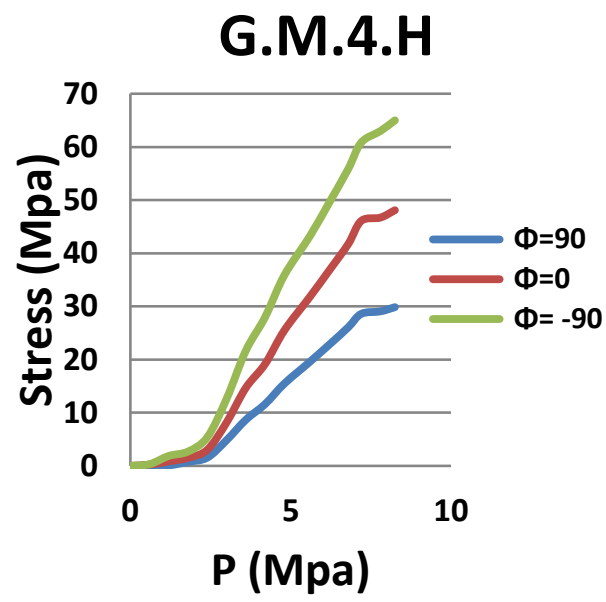

Figure (18) Stress hoop $\left(\sigma_{H}\right)$, for woven fiber glass, with angle $\Phi=90$, $\Phi=0, \Phi=-90$

\section{G.M.3.H}

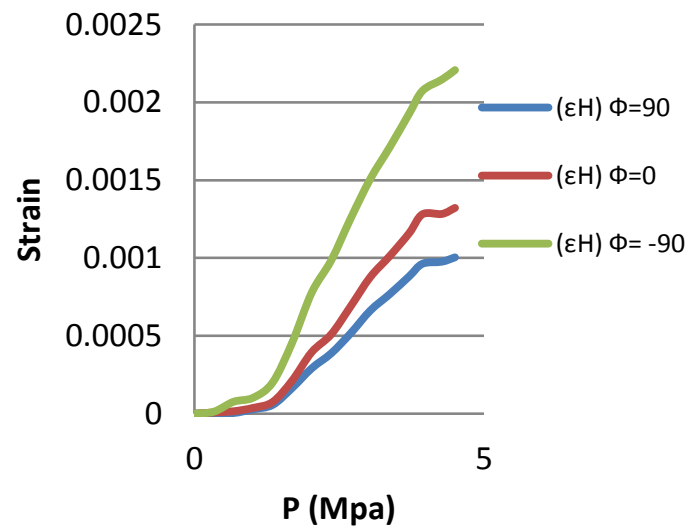

Figure (20) Hoop strain $\left(\varepsilon_{H}\right)$, for glass woven roving, with angle $\Phi=90$, $\Phi=\mathbf{0}, \Phi=\mathbf{~} 90$

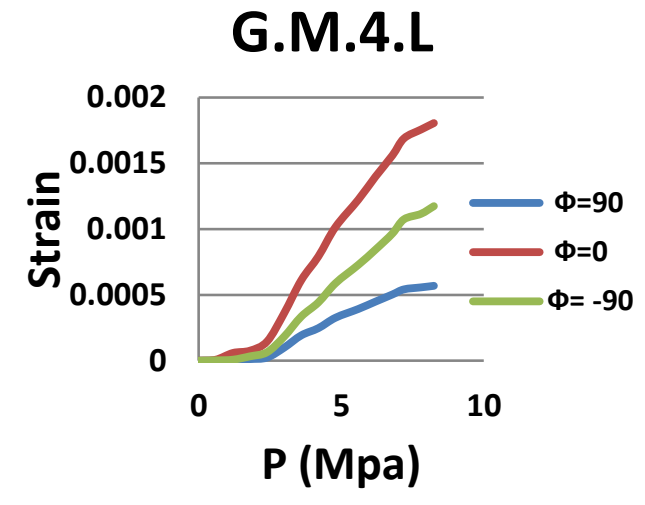

Figure (17) longitudinal strain $(\varepsilon L)$, for glass Woven roving, with angle $\Phi=90$, $\Phi=\mathbf{0}, \Phi=-90$

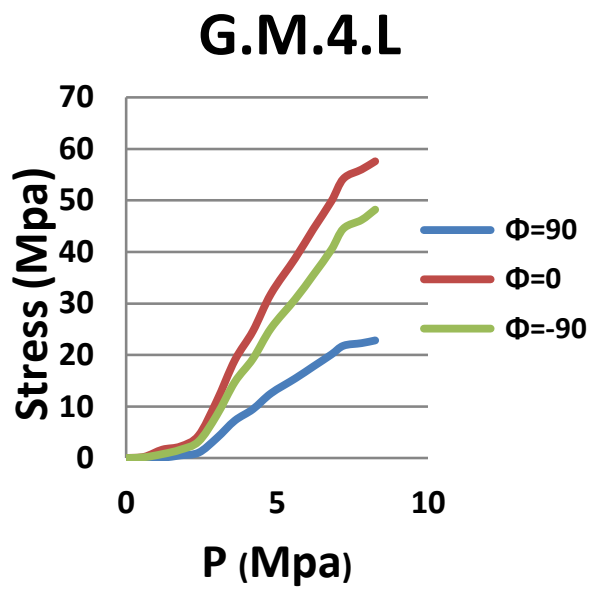

Figure (19) Stress longitudinal $(\sigma L)$, for woven fiber glass, with angle $\Phi=90$, $\Phi=\mathbf{0}, \boldsymbol{\Phi}=\mathbf{- 9 0}$

\section{G.M.3.L}

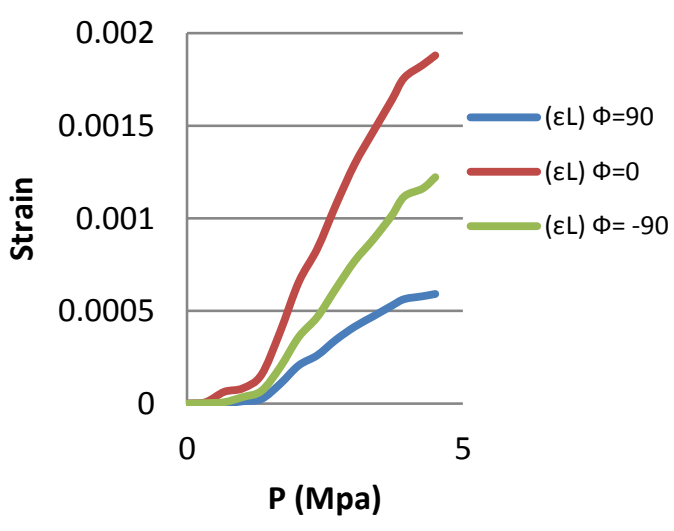

Figure (21) longitudinal strain $(\varepsilon L)$, for glass roving, with angle $\Phi=90, \Phi=0, \Phi=$ $-90$ 
Figures (24), (25) and (26) shows the effects of combined internal pressure reaching up to (3.8) $\mathrm{MPa}$ and bending load up to $(1650 \mathrm{~N})$ on the stresses [hoop stress $\left(\sigma_{H}\right)$, longitudinal stress $\left(\sigma_{L}\right)$ and von mises stress $\left.\left(\sigma_{V o n}\right)\right]$ for (G.M.4), at three angles [ $\Phi=90^{\circ}, \Phi=-90^{\circ}, \Phi=0$ ]. It is noted that all stresses increased with the growing in pressure. It can be observed from figure that by add the closing bending load to the internal pressure, both the longitudinal and hoop stresses decrease compared with the curved pipe in the case of internal pressure only. This means that the outward forces from internal pressure are acting in an opposite direction of action from the closing bending load. This leads to a reduction in stress compared the case of internal pressure only, known as the pressure reduction effect, therefore the two effects are rejected to each other. Also, note that the hoop stress $\left(\sigma_{H}\right)$ in angle $\left(\Phi=-90^{\circ}\right)$ in figure (24) is more than $\left(\sigma_{H}\right)$ in the crown position by $(48 \%)$ while $\left(\sigma_{H}\right)$ in angle $\left(\Phi=0^{\circ}\right)$ is more than $\left(\sigma_{\mathrm{H}}\right)$ in the extrados position by $(62 \%)$. Also, note that the longitudinal stress $\left(\sigma_{\mathrm{L}}\right)$ in angle $\left(\Phi=0^{\mathrm{O}}\right)$ in figure (25) is more than the $\left(\sigma_{\mathrm{L}}\right)$ in the intrude position by $(42 \%)$, As well as the longitudinal stress $\left(\sigma_{L}\right)$ in $\left(\Phi=-90^{\circ}\right)$ is more than $\left(\sigma_{L}\right)$ in extrados position by $(89 \%)$. In addition the von mises stress $\left(\sigma_{V_{\text {on }}}\right)$ in angle $\left(\Phi=-90^{\circ}\right)$ in figure (26) is little more than the $\left(\sigma_{V}\right)$ in the crown position by $(5 \%)$ while the $\left(\sigma_{V o n}\right)$ in angle $\Phi=0^{\mathrm{O}}$ (crown position) is more than the $\left(\sigma V_{\mathrm{V} n}\right)$ in the extrados position by $(116 \%)$. as listed in table (5).

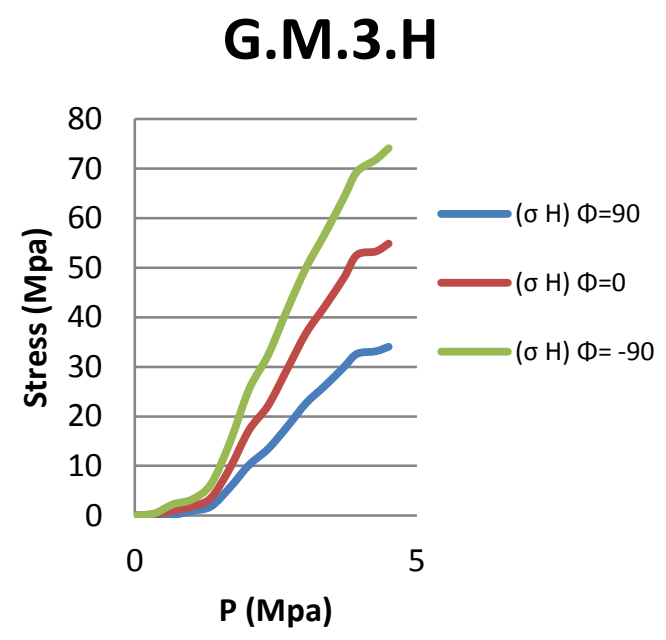

Figure (22) hoop stress $(\sigma H)$, for fiber Roving, with angle $\Phi=90, \Phi=0, \Phi=-90$

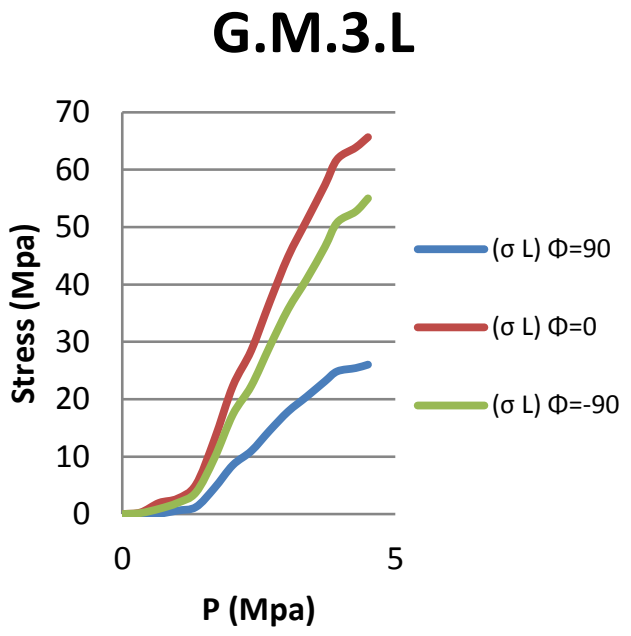

Figure (23) longitudinal stress $(\sigma L)$, for fiber roving, with angle $\Phi=90$, $\Phi=0, \Phi=$.90 
Journal of University of Babylon for Engineering Sciences, Vol. (26), No. (7): 2018.

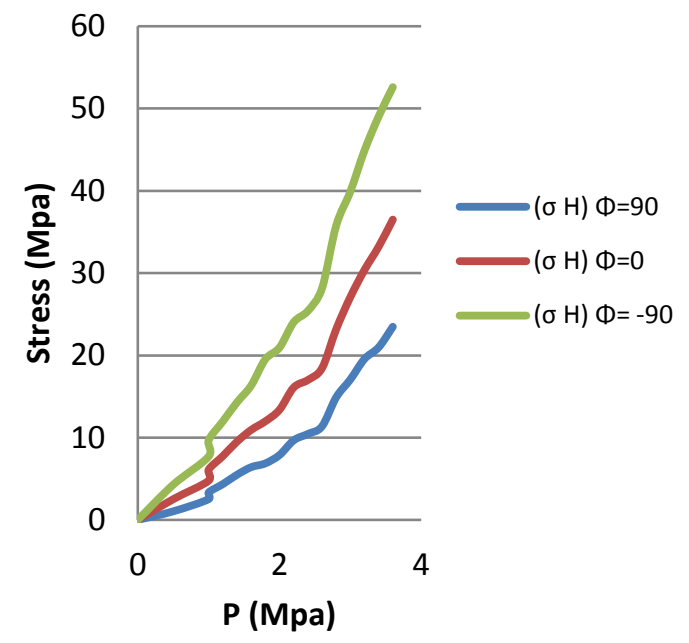

Figure (24) hoop stress $(\sigma H)$, for glass roving، with angle $\Phi=90, \Phi=0, \Phi=~-90$ and internal pressure with $(1650 \mathrm{~N})$ load

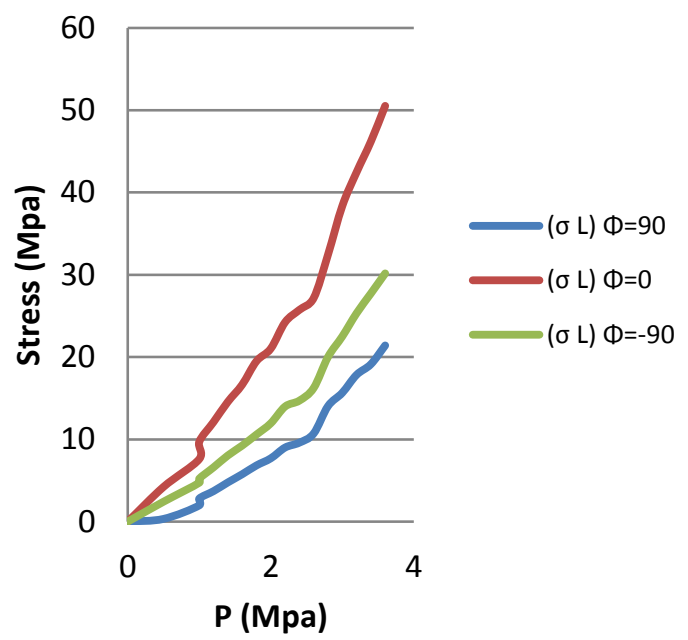

Figure (25) longitudinal stress $(\sigma L)$, for glass roving, with angle $\Phi=90, \Phi=0, \Phi=$ 90 and internal pressure with $(1650 \mathrm{~N})$

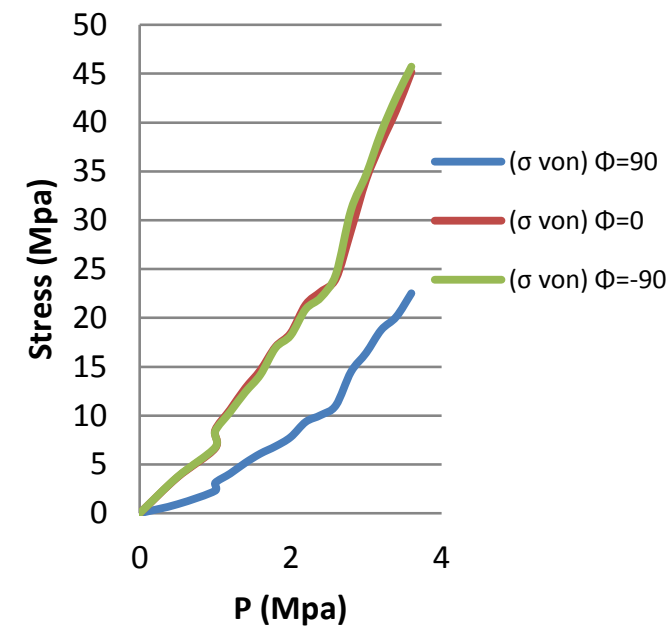

Figure (26) von Mises Stress for glass roving, with angle $\Phi=0, \Phi=$ $90^{\circ}, \Phi=90^{\circ}$ and internal pressure with $(1650 \mathrm{~N})$ load

Table (5) Results of the for fiber for curved pipe under combined internal pressure and bending load

\begin{tabular}{|c|c|c|c|c|c|c|c|c|c|c|c|}
\hline \multirow[t]{2}{*}{ MAT. } & \multirow{2}{*}{$\begin{array}{l}\mathrm{F} \\
\mathrm{N}\end{array}$} & \multirow{2}{*}{$\begin{array}{c}\mathrm{P} \\
\mathrm{Mpa}\end{array}$} & \multicolumn{3}{|c|}{$\Phi=-90^{\circ}$} & \multicolumn{3}{|c|}{$\Phi=0^{\mathbf{O}}$} & \multicolumn{3}{|c|}{$\Phi=90^{\mathbf{0}}$} \\
\hline & & & $\begin{array}{c}\sigma \mathrm{H} \\
(\mathrm{Mpa})\end{array}$ & $\begin{array}{c}\sigma \mathrm{L} \\
(\mathrm{Mpa})\end{array}$ & $\begin{array}{l}\sigma \text { von } \\
(\mathrm{Mpa})\end{array}$ & $\begin{array}{c}\sigma \mathrm{H} \\
(\mathrm{Mpa})\end{array}$ & $\begin{array}{c}\sigma \mathrm{L} \\
(\mathrm{Mpa})\end{array}$ & $\begin{array}{l}\sigma \text { von } \\
(\mathrm{Mpa})\end{array}$ & $\begin{array}{c}\sigma \mathrm{H} \\
(\mathrm{Mpa})\end{array}$ & $\begin{array}{c}\sigma \mathrm{L} \\
(\mathrm{Mpa})\end{array}$ & $\begin{array}{l}\sigma \text { von } \\
(\mathrm{Mpa})\end{array}$ \\
\hline G.M.4 & 1650 & 3.8 & 52.5 & 30.1 & 45.7 & 36.4 & 50.5 & 45 & 23.4 & 21.4 & 22.5 \\
\hline
\end{tabular}




\section{Conclusions}

In this work, the main conclusions are:

1. The specimens of the woven roving (MAT) glass fiber at thickness $(4 \mathrm{~mm})$ in hoop direction at inner arc (intrude) and longitudinal direction at in the middle (crown) of curved pipe at $4 \mathrm{~mm}$ thickness respectively were more tolerant to stresses, and strain than their counterparts at $(3 \mathrm{~mm})$ thickness.

2. The most critical region at inner arc of the curved pipe, which represents the area of (intrude) in the bend tube. The region in outer arc (extrados) of curved pipe is lower in all cases during the sample test under internal pressure.

3. The hoop stresses and strain are more than longitudinal stresses and strain at inner arc. Longitudinal stresses and strain more than hoop stresses and strain in the middle (crown) of curved pipe.

4. Conclude that the weakest or critical area in the curved pipe is located at the inner arc or intrude area and in the lateral area in the middle (crown) of curved pipe. The least concentrated area of stress and strain in the in outer arc (extrados) of curved pipe.

5. The maximum stresses for curved composite pipe with in-plane bending and internal pressure were less than maximum stresses for curved composite pipe subjected to internal pressure only.

\section{References}

[1] Wood".A review of Literature for the Structural Assessment of Mitred bends ". International Journal of Pressure Vessels and Piping vol. 85, pp. 275-294، 2008.

[2] Long B.T., "Experimental Characterization of GRE Composite for Failure Envelope Validation . 10th International Conference on Composite Science and Technology ICCST/10، 2015.

[3] Hashem M., "Elastic-Plastic Behavior and Limited Load Analysis of Pipe Bends Under Out-of Plane Moment Loading and Internal Pressure". M.Sc. Thesis. American University in Cairo School of Sciences and Engineering Department, 1999.

[4] Duncan C., "Composite Fiber Reinforced Pipe Elbow Subject to Combined Loading". Proceedings of the ASME 2017 Journal of Pressure Vessels and Piping Conference PVP 2017, July 16-20, 2017.

[5] Cesar G., "Stress Intensification Factors at Pipe Elbows". Journal of ME 404, 2013.

[6] Long B.T., "Finite Element Modeling of Buride Glass- Reinforced Composite "10th International Conference on Composite Science and Technology ICCST/10, 2015.

[7] Chitoshi M., "Deformation and Fracture Properties OF Steel Pipe Bend with Internal Pressure Subject to In- Plane Bending", Tokyo Japan, Journal of 12WCEE, 1814, 2000.

[8] DATASHEET NI 9235." Operating Instruction and Specification NI 9235/9236 Channel, 24-Bit Quarter-Bridge Analog Input Module", 2015.

[9] American Society for Testing and Materials International. "Standard Test Method for Tensile Properties of Plastics”, 2000.

[10] Chen S.Y., Chen J., Liu C.D.,“ Stress Analysis Engineering Design of Reducer Bend Under Internal Pressure "14th International Conference of Pressure Vessels Technology, pp. 57-66, 2015. 


\title{
تأثير الاجهادات المركبة على الياف ايبوكسي الأنابيب المنحنية المركبة
}

\author{
عمر عماد شكري \\ فاضل عباس عبد الله \\ قسم الهندسة المبكانيكبة، جامعة المستنصرية، بغد/د، العراق.
}

fadhe1975@yahoo.com

\section{الخلاصة}

الهدف من هذا البحث هو در اسة سلوك أنبوب منحنى الألياف المركبة من الإيبوكسي تحــت الضــغط

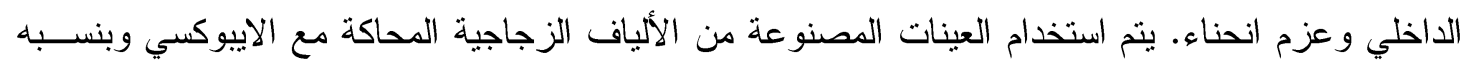

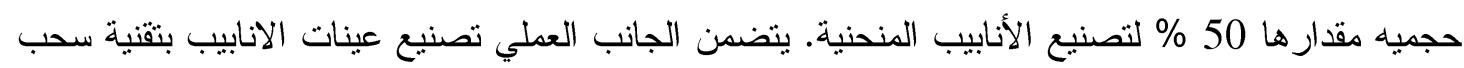

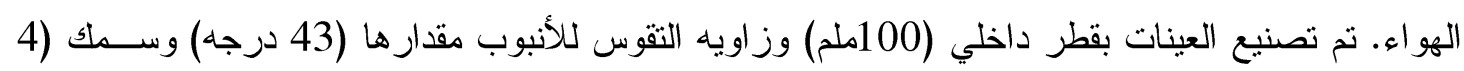
و 3 ملم). تم ايضا تصميم جهاز اختبار لدر اسة تأثير الضغط الداخلي وعزم انحناء على الأناييــبـ المركبـــة.

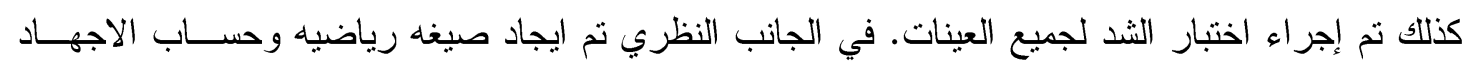
و الانفعال الطولي و المحيطي. من الواضح أن الاجهاد المحيطي للأنابيب المنحنية المركبة من الألياف الزجاج

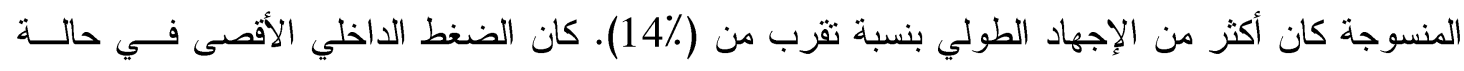
الضغط الداخلي فقط أكثر بالمقارنة مع الضغط الداخلي جنبا إلى جنب مع عزم الانحناء بنسبه (115\%).

$$
\text { العثور على أخطر منطقة في القوس الداخلي (التقعر) للأنبوب المنحني. }
$$

